\title{
Effects of Boron Omission and Foliar Fertilization on Nutrition Efficiency and Production of Cowpea
}

Sylvia Letícia Oliveira Silva², Renato de Mello Prado, Gilmara Pereira da Silva ${ }^{1}$, and Gabriel Barbosa da Silva Júnior ${ }^{1}$ Department of Soils and Fertilizers, School of Agricultural and Veterinarian Sciences (UNESP/FCAV), State University of São Paulo, access pathway Prof. Paulo Donato Castellane, Jaboticabal, São Paulo State, CP 14884900, Brazil

\author{
Monica Lanzoni Rossi ${ }^{1}$ \\ Centro de Energia Nuclear na Agricultura, Universidade de São Paulo, Av. \\ Centenário, 303, São Dimas, Piracicaba, São Paulo State, CP 13400-970, \\ Brazil
}

\section{Leónides Castellanos González ${ }^{1}$}

Department of Soils and Fertilizers, Faculty of Agriculture and Veterinary Sciences, Paulista State University "Julio de Mesquita Filho," access pathway Prof. Paulo Donato Castellane, Jaboticabal, São Paulo State, CP 14884-900, Brazil

Additional index words. Vigna unguiculata, plant nutrition, crop quality, nutrient management, sorbitol

\begin{abstract}
This study aimed to evaluate the effects of boron (B) omission on cowpea nutrition and to compare the impact of foliar $B$ fertilization with and without sorbitol on cowpea growth, nutritional status, and B uptake. Two trials using a completely randomized experimental design were conducted. During the first experiment, nutrient solution was provided without $B(-B)$ and with $B(+B)$ in 10 replicates. During the second experiment, a $5 \times 2$ factorial treatment scheme was used. Five $B$ concentrations $(0,1.25$, 2.5, 3.75, and $5.0 \mathrm{~g} \cdot \mathrm{L}^{-1}$ ) were administered foliarly in the form of boric acid with or without sorbitol $\left(500 \mathrm{mmol} \cdot \mathrm{L}^{-1}\right)$ in four replicates. B omission symptoms, root growth, plant organ dry mass and $B$ content, and grain yield were evaluated. B omission induced greater losses in reproductive organ and root growth than in leaf and stem production. It also caused deformation of the middle lamella and accumulation of starch in the chloroplasts. Foliar applications of 2.6 to $2.9 \mathrm{~g} \cdot \mathrm{L}^{-1} \mathrm{~B}$ improved cowpea production. The addition of sorbitol did not enhance plant growth. However, it increased B absorption in the vegetative parts of the plant but did not enhance seed production.
\end{abstract}

Foliar fertilization is an important agricultural practice for sustainable management and is used to help increase the yield of annual crops such as cowpea (Fernández et al., 2013). This technique is used to correct nutritional deficiencies, mainly micronutrients such as boron (B) (Fernández and Brown, 2013), because of their low availability in the soil (Rodríguez-Lucena et al., 2009).

Boron deficiency in Fabaceae causes significant crop losses by restricting reproductive development (Chatterjee et al., 2014)

Received for publication 19 Apr. 2018. Accepted for publication 27 Aug. 2018.

We gratefully acknowledge Instituto Federal do Maranhão for the scholarship granted to the first author.

This article was part of a thesis submitted by one of the authors in fulfillment of a degree requirement. ${ }^{1}$ Co-first authors.

${ }^{2}$ Corresponding author. E-mail: sylvia.leticia@ ifma.edu.br. and root growth (Hajiboland et al., 2012). Furthermore, B deficiency, particularly in the roots, significantly influences the composition of the intermediates and end products in the shikimic pathway (such as quinones) (Dong et al., 2016). Moreover, B deficiency causes the plant to break down carbohydrates via the pentose phosphate pathway rather than by glycolysis, thus leading to the formation of phenolic compounds and tryptophan (Kirkby and Römheld, 2007).

$\mathrm{B}$ is the second most demanded micronutrient in cowpea (Araújo et al., 1984; Oliveira and Dantas, 1984), and its deficiency limits crop productivity. This B deficiency may induce changes in the cell wall and cause middle lamella thickening, chloroplast deformation in castor (Ricinus communis) (Lavres Júnior et al., 2012), and starch grain accumulation in cowpea (Vigna unguiculata) leaf chloroplasts (Inbaraj and Muthuchelian, 2011).

Foliar B application is a technique used to correct the deficiency of this micronutrient in Fabaceae, such as in the common bean
(Phaseolus vulgaris L.) (Rahman et al., 2014). However, there have been no studies of the benefits of foliar B application for cowpea [Vigna unguiculata (L.) Walp.].

One strategy to increase foliar uptake efficiency is to prepare a spray syrup (polyols such as sorbitol) with the appropriate amount of the nutrient (e.g., B) that would ensure optimal leaf nutrient levels. This is because the polyols have a wetting action, thus delaying the drying of the solution by lowering the deliquescent point of the formulation (B plus sorbitol) in the leaf and prolonging the absorption process (Will et al., 2011). The combination of sorbitol and B could also increase the mobility of the micronutrient in the phloem, thereby prolonging the residual effect of foliar fertilization. The effect of sorbitol increasing B mobility was observed in plants that naturally produce polyols and have a polyol:B ratio more than 100:1 in the phloem (Brown and Hu, 1996). Nevertheless, it is uncertain whether the application of B in sorbitol syrup would improve the phloem translocation of this nutrient in grain production. It has been reported that sorbitol had no effect on $\mathrm{B}$ redistribution in soybean plants (Will et al., 2011). This might be explained by the formation of a poorly soluble polyol-B-polyol complex limiting the amount of $\mathrm{B}$ that can reach the phloem.

There are few studies of B omission in Fabaceae, and none of these studies refers to cowpea. Therefore, studies are required to increase the understanding of the effects of B limitation in this species at the cellular level and its influence on plant dry mass accumulation.

Two hypotheses were formulated regarding $\mathrm{B}$ nutrition in cowpea: a) B omission reduces cowpea productivity by causing the plant to allocate fewer resources to the formation of reproductive tissues and by causing cellular alterations that account for the characteristic omission symptoms in the vegetative tissues and b) foliar B fertilization is essential for cowpea production regardless of whether sorbitol is added and increases the harvest index rather than the dry matter of the vegetative organs. Therefore, the effects of $B$ omission on cowpea nutrition and on plant nutrition and the effects of foliar B fertilization with or without sorbitol on cowpea growth, nutritional status, and B accumulation should be evaluated.

\section{Materials and Methods}

Two experiments were conducted. The first used cowpea and a floating type of hydroponic farming system. The second was performed in sand. Both were performed in a greenhouse in Jaboticabal, Brazil.

\section{Expt. 1}

The first experiment involved a completely randomized design with two treatments: complete nutrient solution without $B$ $(-\mathrm{B})$ and complete nutrient solution with $\mathrm{B}$ (+B). There were 10 replicates. Experimental units consisted of two plants per pot. 
Thirteen days after sowing, two cowpea (Vigna unguiculata) seedlings were transferred to pots $\left(8 \mathrm{dm}^{3}\right)$ containing Hoagland solution (Hoagland and Arnon, 1950). The iron source was changed from Fe-EDTA to Fe-EDDHMA. The nutrient solutions were diluted during the first and second weeks of culture to $25 \%$ and $50 \%$ of the ionic strength, respectively. During the third week of culture, the full-strength nutrient solution was used.

Nutrient solutions were prepared with deionized water and replaced every $15 \mathrm{~d}$. The $\mathrm{pH}$ levels of the nutrient solutions were adjusted using $\mathrm{NaOH} 1.0 \mathrm{~N}$ or $\mathrm{HCl} 0.1 \mathrm{~N}$ solution. Deionized water was used to replenish that lost by evapotranspiration. Furthermore, the nutrient solutions were constantly oxygenated using an air compressor.

Data regarding the average temperature and relative humidity were collected daily in the greenhouse using a digital thermo hygrometer (ITHT-2250; Instrutemp, São Paulo, Brazil) from sowing to harvest (8 weeks) (Fig. 1). At $70 \mathrm{~d}$ after sowing (the end of the plant cycle), plants were cut at the crown level, thereby separating the shoot from the root system. The leaf area was measured using a leaf area meter (L-3100; LI-COR, Lincoln, NE).

To analyze the root length $(\mathrm{mm})$, area $\left(\mathrm{mm}^{2}\right)$, and density $\left(\mathrm{mm} \cdot \mathrm{mL}^{-1}\right)$, samples comprising $1 \mathrm{~g}$ of fresh root tissues from each plant were stained with methylene blue for $\approx 2 \mathrm{~min}$. Then, the roots were arranged on a water tray, where the image was read by a Hewlett Packard Model 5C scanner (Delta-T SCAN; Hewlett Packard, Cambridge, UK). The image of each root system was analyzed using an image analysis system and software (Delta-T Devices Ltd, Cambridge, UK).

The harvested plant material was washed with deionized water and separated into roots, leaves, stems, pods, and grains. The samples were dried in a forced ventilation oven at $65{ }^{\circ} \mathrm{C}$ until constant dry matter was obtained for all organs except the grains. Plant materials were then milled, and their B content was determined following the methodology described by Bataglia et al. (1983). The harvest index, which is the ratio of grain mass to aerial shoot mass, was also calculated.

Accumulations of B in the roots, stems, pods, leaves, and grains ( $\mu \mathrm{g} /$ plant) were calculated from the $\mathrm{B}$ content and the dry matter and from the B accumulation in the roots and the aerial shoot. Nutrient uptake efficiencies were calculated as follows: absorption efficiency $=($ total B content in the plant)/(root dry matter) (Swiader et al., 1994) and efficiency of use of B = (total dry matter produced $)^{2} /($ total B content in the plant) (Siddiqi and Glass, 1981).

During the experimental period, pictures of the plants were taken showing B omission symptoms and were compared with the controls. Descriptions of the symptoms were recorded.

When nutrient omission symptoms appeared, ultrastructural cellular modifications in the leaf mesophyll were evaluated using 10 completely expanded leaves from the control plants and from the B-deficient plants. Leaf blade samples $\left(1-2 \mathrm{~mm}^{2}\right)$ were fixed for $3 \mathrm{~h}$ at $4{ }^{\circ} \mathrm{C}$ in the following modified solution Karnovsky (1965): 2\% glutaraldehyde, $2 \%$ paraformaldehyde, and $5 \mathrm{~mm}$ calcium chloride in $0.05 \mathrm{M}$ sodium cacodylate buffer ( $\mathrm{pH}$ 7.2). The lamina samples were then washed in $0.1 \mathrm{M}$ cacodylate buffer and fixed with $1 \%$ osmium tetroxide in $0.1 \mathrm{M}$ sodium cacodylate buffer. After rapid washes with $0.9 \%$ saline solution, contrast was added to the samples for overnight treatment with $2.5 \%$ uranyl acetate. Samples were then dehydrated using an
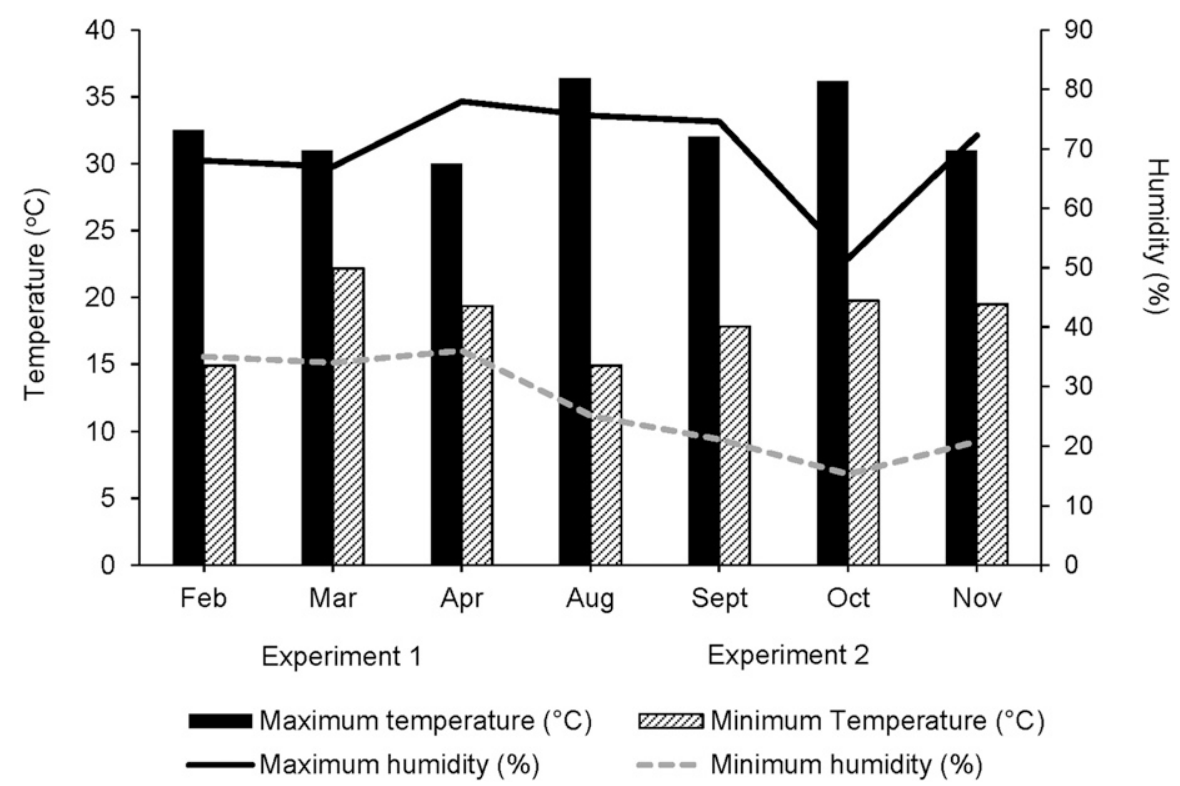

Fig. 1. Weekly mean values for air temperature and relative humidity in the greenhouse over the course of the experiment.

aqueous acetone solution series $(25 \%, 50 \%$, $75 \%, 90 \%$, and 100\%). Samples were embedded by immersion in Spurr resin for $48 \mathrm{~h}$ at $70{ }^{\circ} \mathrm{C}$. Ultra-thin sections (thickness, 60-90 $\mathrm{nm}$ ) were deposited on 300 mesh copper screens and then contrasted with $2.5 \%$ uranyl acetate and lead citrate according to the method of Reynolds (1963). Samples were viewed under a Jeol transmission electron microscope (JEM 1010; Akishima, Tokyo, Japan).

\section{Expt. 2}

Treatments. The experimental design was a randomized block with four replicates in a $5 \times 2$ factorial scheme with five concentrations of $\mathrm{B}\left(0,1.25,2.5,3.75\right.$, and $\left.5.0 \mathrm{~g} \cdot \mathrm{L}^{-1}\right)$ in the form of boric acid $(17 \% \mathrm{~B})$ with or without sorbitol $\left(500 \mathrm{mmol} \cdot \mathrm{L}^{-1}\right)$ (Will et al., 2012). Nine days after sowing the cowpea cultivar BRS-Guariba, when the seedlings had two to three pairs of fully formed leaves, they were transplanted to plastic pots $\left(3 \mathrm{dm}^{3}\right)$ containing washed sand.

The plants were irrigated daily with Hoagland's solution (Hoagland and Arnon, 1950) without B prepared using deionized water. The iron source was Fe-EDDHMA, and the $\mathrm{pH}$ was maintained between 5.5 and 6.0. The nutrient solution was diluted to $25 \%$ of ionic strength during the first week of cultivation, $50 \%$ during the second week, and $100 \%$ thereafter until the end of the experiment. The pots had collecting vessels under them to recover drainage of the nutrient solution.

Foliar fertilization. Foliar B applications were performed at 20,40, and 50 days after transplanting (DAT), corresponding to the phenological stages V5, R1, and R2. The nutrient was applied with a 1-L manual sprayer. The following average air temperatures and relative humidity levels were used: $25{ }^{\circ} \mathrm{C}$ and $50 \%, 30{ }^{\circ} \mathrm{C}$ and $70 \%$, and $30{ }^{\circ} \mathrm{C}$ and $10 \%$, respectively. The solutions $(0.25$, 0.40 , and $0.50 \mathrm{~mL}$ of $\mathrm{B}$ per plant) were defined by a blank test (water solution and dropper adhesive) $1 \mathrm{~d}$ before each preestablished time for spraying the nutrient. The diagnostic leaf, which was the third leaf with the petiole intact, was sampled from the middle third of each plant at the flowering stage to determine the B content of the plant (van Raij et al., 1996).

Average greenhouse air temperature and relative air humidity data were collected daily using a digital thermo hygrometer digital (ITHT-2250; Instrutemp) from sowing to harvest (15 weeks) (Fig. 1). Pods were harvested three times (at 52, 72, and 90 DAT). The pods were manually threshed, the grains were weighed, and the yield at $13 \%$ moisture was calculated. At the end of the experiment (103 DAT), the plants were harvested and separated into roots, leaves, stems, and pods.

Preparation of the samples. All plant organs were washed and dried in a forced ventilation oven at $65^{\circ} \mathrm{C}$ to a constant matter. Dry matter of the roots, stems and pods without grains, leaves, and grains were obtained. The dry matter of the aerial shoot was calculated from the sum of the dry matter of 
the leaves and stems and pods without grains. The harvest index, which is the ratio of the dry matter of the grains to the total dry matter, was also determined. The plant material was milled and the B content was measured using the same methodology as that used for Expt. 1 .

$\mathrm{B}$ accumulations in the roots, aerial shoot (leaves and stems and pods without grains), and grains were calculated based on B content and dry matter. The efficiency of B use was calculated in a manner similar to that described for Expt. 1 and was based on the B content in the roots and shoots.

Statistical analyses. During both experiments, the data were subjected to analysis of variance using the $\mathrm{F}$ test $(P \leq 0.05)$. In Expt. 2 , the means were compared using the Tukey test $(P \leq 0.05)$, and polynomial regression analyses were applied to the B doses. A Pearson correlation analysis $(P \leq 0.05)$ was performed between the variables.

\section{Results and Discussion}

\section{Expt. 1}

When the B supply was neglected, there was a decrease in its accumulation in the roots, stems and pods, leaves, and grains, and in its absorption efficiency. However, B deficiency improved its use efficiency, which enhanced dry mass content when compared with the control treatment (Table 1). This might be a strategy for increasing the use of this nutrient according to the metabolism of the plant.

Decreased B accumulation in plants deficient in this micronutrient (Table 1) resulted in decreased root and shoot dry matter production (Table 2). Decreased root production can be associated with root length, area, and density, which were decreased in the absence of B. The lack of B decreased the leaf area, dry matter of the root, stems and pods, and leaves, and it decreased the yield by $23 \%$, $40 \%, 30 \%, 30 \%$, and $60 \%$, respectively, relative to those of the control plants. The effects of B deficiency on root and shoot growth were previously reported for Vigna radiata L. (Singh et al., 2014).

The lack of B caused a decrease in yield (Table 2) due to its correlation (Table 3) with grain dry matter and the harvest index $(r=$ $\left.0.94^{* *}\right)$ and the dry matter of the leaves $(\mathrm{r}=$ $0.62 *)$ and stems and pods $\left(\mathrm{r}=0.50^{*}\right)$. Therefore, $\mathrm{B}$ omission caused a greater reduction in reproductive tissue than in vegetative tissue. Similar findings were reported for other legume species such as lentil (Lens culinaris Medik) (Karan et al., 2014), green gram (Vigna radiata) (Padbhushan and Kumar, 2015), and the common bean (Phaseolus vulgaris L.) (Harmankaya et al., 2008). Bogiani and Rosolem (2012) reported that B deficiency caused rapid inhibition of root growth in cotton, possibly as a result of the induction of auxin synthesis (CamachoCristóbal et al., 2015).
Twenty-five days after the seedlings were transplanted to B-deficient nutrient solution, the new leaves became deformed, chlorotic, and eventually necrotic (Fig. 2B). At the end of the cycle, the roots were underdeveloped (Fig. 2A). The deficiency caused a decrease in the number of pods and grains per plant and the grain size. The grains that did develop were deformed (Fig. 2C).

Ultrastructural analysis revealed a thickening of the middle lamella in the mesophyll cells of B-deficient cowpea leaves (Fig. 3E) in comparison with those in control plants (Fig. 3F). The changes in the cell wall structure and thickening of the middle lamella attributable to B deficiency were reported for castor bean (Ricinus communis) by Lavres Júnior et al. (2012) and for Brassica napus by Pan et al. (2012). In the absence of $\mathrm{B}$, newly synthesized pectin chains do not bind to cell walls, resulting in spongy tissues and cell wall thickening (Chatterjee et al., 2014). This mechanism may account for the deformation of younger cowpea leaves with B deficiency (Fig. 2B).

Numerous starch grains were observed in the chloroplasts of B-deficient plants (Fig. 3B and F). Similar findings were reported for the leaf cells of Vigna unguiculata (Inbaraj and Muthuchelian, 2011). The authors explained that the starch accumulation in B-deficient leaves may adversely affect the structure and function of chloroplasts and lead to decreased chlorophyll content.

Table 1. Accumulation of B in roots (RAC), stems and pods (SPAC), leaves (LAC), and grains (GAC) and efficiency of absorption (EA) and efficiency of use of $\mathrm{B}(\mathrm{EU})$ in cowpea according to the absence and presence of $\mathrm{B}$ in the nutrient solution.

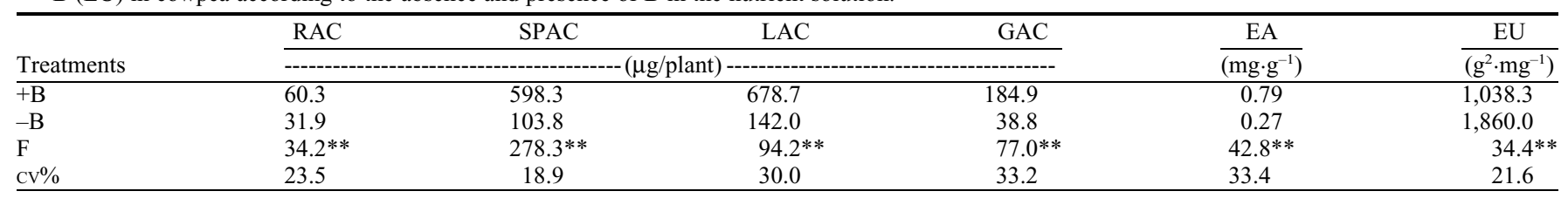

$\mathrm{CV}=$ coefficient of variation. $* * P \leq 0.01$ according to the $\mathrm{F}$ test.

Table 2. Leaf area (LA), root length (RL), root area (RA), root density (RD), root dry matter (RDM), stem and pods dry matter (DMSP), leaf dry matter (DML), grain production (Prod.), and harvest index (HI) of cowpea as a function of the absence (-B) and presence (+B) of boron in the nutrient solution.

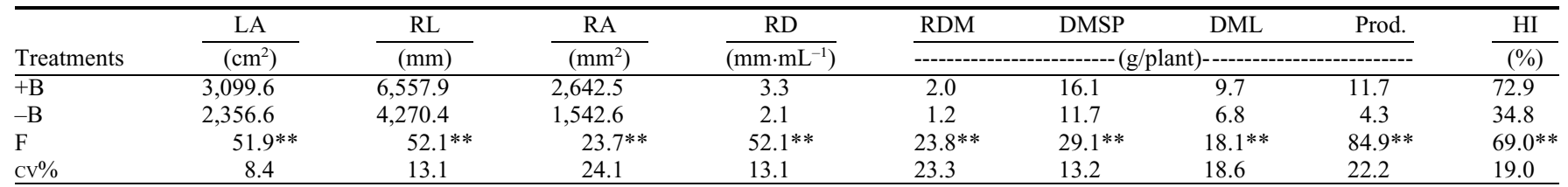

$\mathrm{CV}=$ coefficient of variation. ${ }^{* *} P \leq 0.01$ according to the $\mathrm{F}$ test.

Table 3. Correlation coefficient of the yield parameter and yield of cowpea. Grain production (Prod.), leaf area (LA), root length (RL), root area (RA), root density (RD), root dry matter (RDM), stem and pods dry matter (DMSP), leaf dry matter (DML), and harvest index (HI) of cowpea.

\begin{tabular}{|c|c|c|c|c|c|c|c|c|c|}
\hline & Prod. & LA & RL & RA & RD & RDM & DMSP & DML & HI \\
\hline RL & & & 1.00 & $0.67 * *$ & $1.00^{* *}$ & $0.62 * *$ & $0.42 * *$ & $0.58 * *$ & $0.74 * *$ \\
\hline RA & & & & 1.00 & $0.67^{* *}$ & $0.68^{* *}$ & $0.52^{* *}$ & $0.45^{*}$ & $0.58^{*}$ \\
\hline RDM & & & & & & 1.00 & $0.59 * *$ & $0.63^{* *}$ & $0.71^{* *}$ \\
\hline DMSP & & & & & & & 1.00 & $0.70^{* *}$ & $0.31^{*}$ \\
\hline DML & & & & & & & & 1.00 & $0.52 *$ \\
\hline
\end{tabular}

Pearson's correlation analysis $(P \leq 0.05)$ was performed between the variables. ${ }^{*} P \leq 0.05 ; * * P \leq 0.01$. 


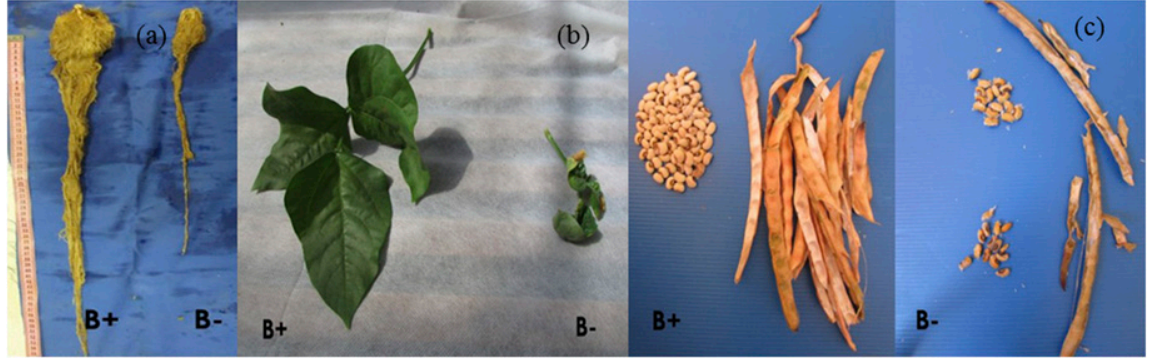

Fig. 2. Cowpea plants cultivated in nutrient solution in the presence $(+B)$ and absence $(-B)$ of boron. (A) Roots, (B) leaves, and (C) grains and pods per plant.

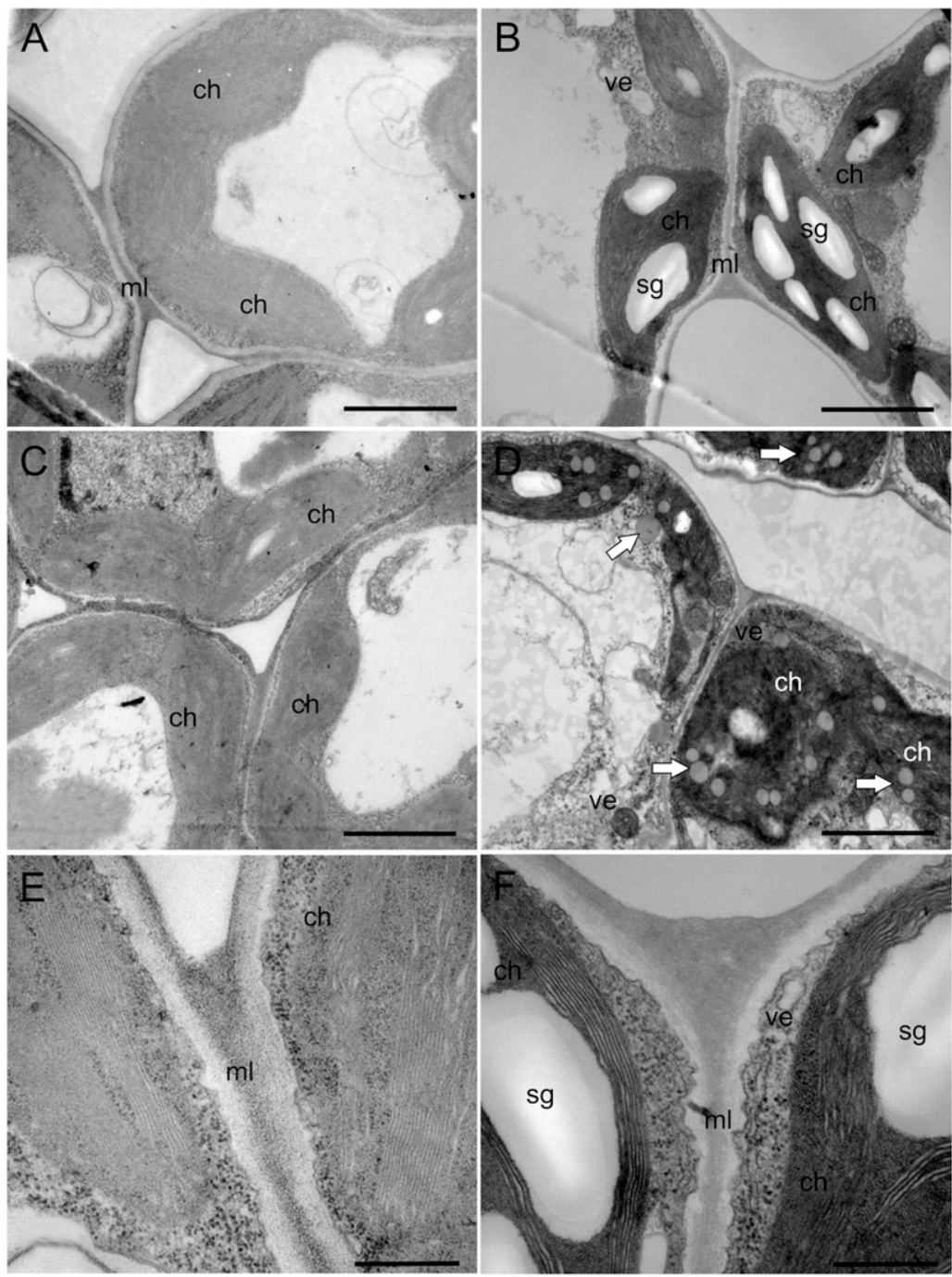

Fig. 3. Ultrastructure of cowpea leaf mesophyll in the presence $(+B)(A, C, \mathbf{E})$ and absence $(-B)(\mathbf{B}, \mathbf{D}, \mathbf{F})$ of boron $\mathrm{Cl}=$ chloroplast $; \mathrm{Ga}=$ starch grain; $\mathrm{Ve}=$ vesicle; $\mathrm{Lm}=$ middle lamella. Arrows indicate lipid bodies. Bars: A-D $=2 \mu \mathrm{m} ; \mathbf{E}-\mathbf{F}=500 \mathrm{~nm}$.

The increase in the number of starch grains in the chloroplasts can decrease photosynthetic rates (Zhang et al., 2015) and alter the chloroplast structure, thus leading to a reduction in chlorophyll content (Inbaraj and Muthuchelian, 2011). Starch biosynthesis occurs in the chloroplasts and amyloplasts and uses sucrose produced from photosynthesis (Galliard and Bowler, 1987) as the base material.
The presence of lipid bodies in the chloroplasts indicated increases in oxidative stress in the photosynthetic apparatus and leaf senescence (Austin et al., 2006). The accumulation of phenols and an increase in polyphenol oxidase activity resulted in the formation of highly reactive intermediates such as quinones. These compounds and photoactivated phenols produce superoxide radicals capable of damaging biological membranes by lipid peroxidation (Kirkby and Römheld, 2007) and inducing foliar necrosis, which was observed in the B-deficient cowpea plants.

\section{Expt. 2}

Foliar B application did not affect dry matter regardless of whether the sorbitol vehicle or carrier was used. Therefore, the plant had low B requirements during the vegetative phase. Reports have indicated weak responses of other plants to B during vegetative growth (Prado, 2008). The inclusion of sorbitol in the syrup in relation to its absence in each B concentration decreased the efficiency of use and increased the accumulation of aerial shoots and B content in the diagnostic leaf at all concentrations of the micronutrient, except for treatment without B. However, the presence of sorbitol in the syrup increased the accumulation of $B$ in the grains only with doses of 3.75 and $5 \mathrm{~g} \cdot \mathrm{L}^{-1}$.

Foliar B application of $\mathrm{B}$ to the leaf promoted a linear increase in the $\mathrm{B}$ content of the leaf. Foliar B uptake was greater when B was applied along with the sorbitol vehicle than when it was applied alone. At the maximum $B$ application rate $\left(5 \mathrm{~g} \cdot \mathrm{L}^{-1}\right)$, the B content in the leaf was $57 \mathrm{mg} \cdot \mathrm{kg}^{-1}$ in the absence of sorbitol and $155 \mathrm{mg} \cdot \mathrm{kg}^{-1}$ in its presence (Table 4).

Foliar B application promoted linear increases in $\mathrm{B}$ accumulation in the root regardless of whether sorbitol was used. Nevertheless, the presence of sorbitol led to an increase in B accumulation in the aerial shoots $(2157$ $\mu \mathrm{g} /$ plant) relative to plants treated with $\mathrm{B}$ alone $(887 \mu \mathrm{g} /$ plant $)$ when the foliar B application rate was $4.37 \mathrm{~g} \cdot \mathrm{L}^{-1}$. Sorbitol, a polyol, may have enhanced foliar B uptake and translocation to the aerial shoot. The beneficial action of polyol for B absorption in the leaf has been reported for soybean (Glycine max) (Will et al., 2012). Sorbitol, like other polyols, is hygroscopic, and its deliquescent point $(69 \%)$ is lower than that of boric acid (98\%) (Salameh et al., 2005). Therefore, sorbitol in the B solution may delay drying of the spray and prolong the contact time on the surface of the leaf (Will et al., 2012).

Foliar B application increased B accumulation in the grains regardless of the presence of sorbitol in the spray syrup, reaching maximas of 417.1 and $474.1 \mu \mathrm{g} /$ plant in the absence and presence of sorbitol, respectively, at B concentrations of 2.90 and 3.09 $\mathrm{g} \cdot \mathrm{L}^{-1}$, respectively.

Although foliar B application increased the yield, the addition of sorbitol to the syrup did not enhance this effect. Foliar B spraying 
promoted greater B accumulation in the vegetative organs, especially in the presence of sorbitol, but not in the reproductive tissues. Sorbitol probably did not promote B redistribution in cowpea; therefore, more of the nutrient could accumulate in the grain as a result of foliar B fertilization. This effect, in turn, increased crop yield. Foliar B application combined with sorbitol is not feasible for cowpea, possibly because the B-sorbitol complex that forms is labile. Polyol-B esters are stable only when the polyol:B ratio exceeds 100:1 (Brown and $\mathrm{Hu}, 1996$ ). In the present study, the polyol:B ratios ranged from $18: 1$ at $5 \mathrm{~g} \cdot \mathrm{L}^{-1} \mathrm{~B}$ to $73: 1$ at $1.25 \mathrm{~g} \cdot \mathrm{L}^{-1} \mathrm{~B}$.

Foliar B application decreased B uptake efficiency, especially when sorbitol was present in the spray syrup. Plants that did not receive sorbitol along with $\mathrm{B}$ had lower $\mathrm{B}$ content in their vegetative tissues and higher B use efficiency, possibly because they allocated more of the nutrient to metabolic processes (Stangoulis et al., 2001). Sorbitol promoted greater B accumulation in the aerial shoots, which, in turn, may have reduced the amount of the nutrient available for metabolism, thereby decreasing the efficiency of the use of $B$.

Cowpea yield reached maximas of $35 \mathrm{~g} /$ plant and $34 \mathrm{~g} /$ plant when foliar B was applied at $2.6 \mathrm{~g} \cdot \mathrm{L}^{-1}$ without sorbitol and $2.9 \mathrm{~g} \cdot \mathrm{L}^{-1}$ with sorbitol. The increase in cowpea yield with B concentrations in the leaf may be attributed to improvements in the nutritional status of the plant. Foliar B was 21.5 to $35.0 \mathrm{mg} \cdot \mathrm{kg}^{-1}$ in the absence of sorbitol and $56.0-94.0 \mathrm{mg} \cdot \mathrm{kg}^{-1}$ when sorbitol was used. Although the use of sorbitol did not result in higher yields, it was suggested that foliar B content in the range of 21.5 to $33 \mathrm{mg} \cdot \mathrm{kg}^{-1}$ is sufficient for cowpea. A similar result was reported by Debnath et al. (2015), who proposed that an adequate foliar B content is $24.5 \mathrm{mg} \cdot \mathrm{kg}^{-1}$ based on analyses of the third fully expanded leaf.

Similar results were also observed in other Fabaceae such as alfalfa (Medicago sativa L.) (Dordas, 2006) and common bean (Phaseolus vulgaris L.) (Rahman et al., 2014). The increase in cowpea yield may have been due to the effect of $B$ on the reproductive phase. The micronutrient was applied twice at this stage (R1 and R2), and it may have helped to keep the stigmata receptive and sticky, thereby increasing pollen efficacy and fertilization, the number of fruits, and the seed mass (Padbhushan and Kumar, 2015).

The elevated concentration of $\mathrm{B}$ in the syrup with sorbitol favored a higher grain yield than the same B concentration without sorbitol. Sorbitol may have attenuated the toxicity of $\mathrm{B}$ in the cowpea plant. The beneficial effect of sorbitol on the mitigation of micronutrient toxicity was demonstrated for rice (Oryza sativa L.) (Theerakulpisut and Gunnula, 2012); therefore, it merits further study.

Foliar B application promoted a quadratic increase in the harvest index, which reached maximas of $46 \%$ and $45 \%$ at $2.6 \mathrm{~g} \cdot \mathrm{L}^{-1}$ and $2.9 \mathrm{~g} \cdot \mathrm{L}^{-1} \mathrm{~B}$ in the absence and presence of sorbitol, respectively. These harvest index values surpassed those reported by Subbarayappa et al. (2009) (18\% to $23 \%)$ for cowpea grown under field conditions, possibly due to the use of different cultivars.

Foliar B application with or without sorbitol improved cowpea reproduction and yield. There was a high positive correlation between the yield and harvest index $(r=$ $0.97^{* *}$ ), and there was a nonsignificant negative correlation between aerial shoot dry matter ( $\mathrm{r}=-0.14$; not significant) and root dry matter $(\mathrm{r}=-0.20$; not significant $)$ (Table 5). It has been widely reported in the literature that foliar B application enhances the reproductive development of Fabaceae but is detrimental to their vegetative growth and development (Dordas, 2006).

\section{Conclusions}

The deficiency of $\mathrm{B}$ in cowpea plants decreased the micronutrient uptake and increased its use efficiency. Such a shortage

Table 4. Dry matter of roots (DMR), aerial shoots (DMAS), boron content in the leaves (Bcont), roots (BCR), aerial shoots (BCAS), grains (BCG), boron use efficiency (UE), grain production (Prod.), and harvest index (HI) with (+S) or without (-S) sorbitol as a function of the concentrations of foliarly applied boron in cowpea. $*$ Significant at $1 \%$ probability according to the $\mathrm{F}$ test at $5 \%$ probability.

\begin{tabular}{|c|c|c|c|c|}
\hline Variable & Equation & $R^{2}$ & Y maxima & $\mathrm{X}$ maxima \\
\hline $\mathrm{DMR}+\mathrm{S}$ & $\mathrm{y}=9,985$ & - & - & - \\
\hline DMAS $-\mathrm{S}$ & $y=43,00150$ & - & - & - \\
\hline $\mathrm{DMAS}+\mathrm{S}$ & $y=43,09602$ & - & - & - \\
\hline $\mathrm{B}$ cont $+\mathrm{S}$ & $y=10,40550+28,85980 x$ & $0.96 * *$ & - & - \\
\hline $\mathrm{BCR}-\mathrm{S}$ & $y=250,43985+13,56399 x$ & $0.67 *$ & - & - \\
\hline $\mathrm{BCR}+\mathrm{S}$ & $y=256,60177+22,54155 x$ & $0,98 * *$ & - & - \\
\hline $\mathrm{BCG}+\mathrm{S}$ & $y=141,61244+214,85822 x-34,711006 x^{2}$ & $0.92 * *$ & $474.1 \mu \mathrm{g} /$ plant & $3.09 \mathrm{~g} \cdot \mathrm{L}^{-1}$ \\
\hline $\mathrm{UE}-\mathrm{S}$ & $y=5182,93882+315,39218 x-122,91883 x^{2}$ & $0.94 * *$ & $5,385.2 \mathrm{~g}^{2} \cdot \mathrm{mg}^{-1}$ & $1.28 \mathrm{~g} \cdot \mathrm{L}^{-1}$ \\
\hline $\mathrm{UE}+\mathrm{S}$ & $y=4943,36845-1318,73514 x+161,98969 x^{2}$ & $0.95 * *$ & $2,259.5 \mathrm{~g}^{2} \cdot \mathrm{mg}^{-1}$ & $4.07 \mathrm{~g} \cdot \mathrm{L}^{-1}$ \\
\hline Prod. -S & $y=15,60600+14,35100 x-2,69200 x^{2}$ & $0.90 * *$ & $34.7 \mathrm{~g} / \mathrm{plant}$ & $2.67 \mathrm{~g} \cdot \mathrm{L}^{-1}$ \\
\hline Prod. $+\mathrm{S}$ & $y=16,46836+11,914629 x-2,053486 x^{2}$ & $0.89^{* *}$ & $33.7 \mathrm{~g} /$ plant & $2.90 \mathrm{~g} \cdot \mathrm{L}^{-1}$ \\
\hline $\mathrm{HI}-\mathrm{S}$ & $y=25,41258+15,41327 x-2,85838 x^{2}$ & $0.95 * *$ & $46.2 \%$ & $2.70 \mathrm{~g} \cdot \mathrm{L}^{-1}$ \\
\hline
\end{tabular}

$* P \leq 0.05 ; * * P \leq 0.01$.

Table 5. Correlation coefficient of the yield parameter and yield of cowpea. grain production (Prod.), dry matter of aerial shoots (DMAS), dry matter of roots (DMR), boron content in the leaves (BCAS), boron content in the roots (BCR), boron content in the grains (BCG), boron use efficiency (UE), boron content (Bcont), and harvest index (HI)

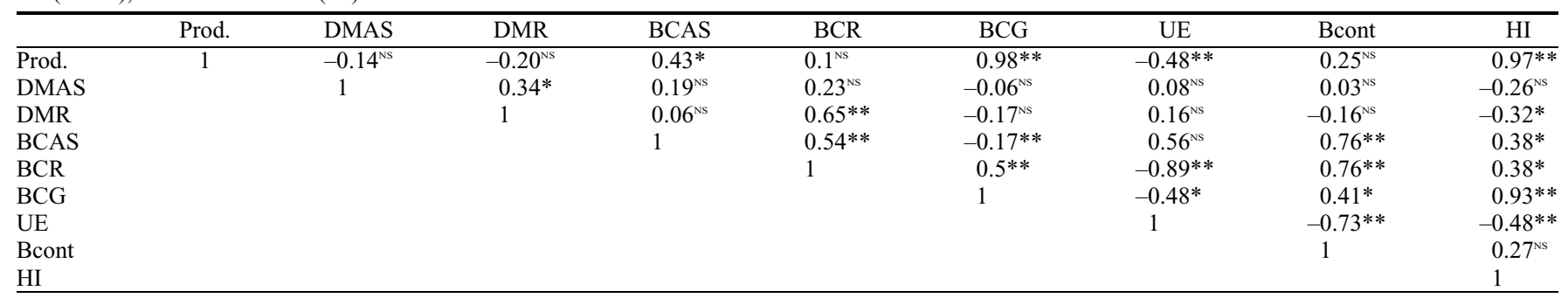

A Pearson correlation analysis $(P \leq 0.05)$ was performed between variables. Ns $=$ nonsignificant; ${ }^{*} P \leq 0.05 ; * * P \leq 0.01$. 
caused greater harm to the growth of roots and reproductive organs than to leaf and stem development. This nutritional disorder induced cell alterations such as middle lamella thickening and starch accumulation in leaf chloroplasts. Combining B and sorbitol in leaf sprays increased the absorption of this micronutrient in vegetative organs but did not increase the yield. Cowpea had a higher yield when B was applied without sorbitol, at a concentration of $2.62 \mathrm{~g} \cdot \mathrm{L}^{-1}$, during three developmental stages (V5, R1, and R2).

\section{Literature Cited}

Araújo, J.P.P., G.P. Rios, E.E. Watt, B.P. Neves, N.K. Fageria, I.P. de Oliveira, C.M. Guimarães, and A. Silveira Filho. 1984. Cultura do caupi. Vigna unguiculata (L.) Walp, descrição e recomendações técnicas de cultivo. EMBRAPA-CNPAF, Goiânia, 82 p. (Circular Técnica, 18).

Austin, J.R., E. Frost, P.A. Vidi, F. Kessler, and L.A. Staehelin. 2006. Plastoglobules are lipoprotein subcompartments of the chloroplast that are permanently coupled to thylakoid membranes and contains biosynthetic enzymes. Plant Cell 18:1693-1703.

Bataglia, O.C., A.M.C. Furlano, J.P.F. Teixeira, P.R. Furlani, and J.R. Gallo. 1983. Métodos de análise química de plantas. Instituto Agronômico, Campinas, 48 p. (Boletim Técnico 78).

Bogiani, J.C. and C.A. Rosolem. 2012. Compared boron uptake and translocation in cotton cultivars. Rev. Bras. Ciên. Solo. 36:1500-1506.

Brown, P.H. and H.N. Hu. 1996. Phloem mobility of boron is species dependent: Evidence for phloem mobility in sorbitol-rich species. Ann. Bot. 77:497-505.

Camacho-Cristóbal, J., E.M. Martín-Rejano, M.B. Herrera-Rodríguez, M.T. Navarro-Gochicoa, J. Rexach, and A. González-Fontes. 2015. Boron deficiency inhibits root cell elongation via an ethylene/auxin/ROS-dependent pathway in Arabidopsis seedlings. J. Expt. Bot. 66:3831-3840.

Chatterjee, M., Z. Tabi, M. Galli, S. Malcomber, A. Buck, M. Muszynski, and A. Gallavottia. 2014. The boron efflux transporter ROTTEN EAR is required for maize inflorescence development and fertility. Plant Cell 26:2962-2977.

Debnath, P., S.K. Pattanaaik, D. Sah, and A.K. Pandey. 2015. Assessment of critical limit of boron for cowpea in piedmont soils of Arunachal Pradesh. Arch. Agron. Soil Sci. 61:1649-1658.

Dembitsky, V.M., R. Smoum, A.A. Al-Quntar, H.A. Ali, I. Pergmament, and M. Srebnik. 2002. Natural occurrence of boron containing compounds in plants, algae and microorganisms. Front. Plant Sci. 163:931-942.

Dong, X., G. Liu, X. Wu, X. Lu, L. Yan, R. Muhammad, A. Shah, L. Wu, and C. Jiang. 2016. Different metabolite profile and metabolic pathway with leaves and roots in response to boron deficiency at the initial stage of citrus rootstock growth. Plant Physiol. Biochem. 108:121-131.
Dordas, C. 2006. Foliar boron application improves seed set, seed yield and seed quality of alfalfa. Agron. J. 98:907-913.

Fernández, V. and P. Brown. 2013. From plant surface to plant metabolism: The uncertain fate of foliar-applied nutrients. Front. Plant Sci. 4:289.

Fernández, V., T. Sotiropoulos, and P. Brown. 2013. Foliar fertilization. Scientific principles and field practices. IFA, Paris, France.

Galliard, T. and P. Bowler. 1987. Morphology and composition of starch, p. 55-78. In: T. Galliard (ed.). Starch properties and potential. Wiley, Chichester.

Hajiboland, R., F. Farhanghi, and M. Aliasgharpour. 2012. Morphological and anatomical modifications in leaf, stem and roots of four plant species under boron deficiency conditions. Ann. Biol. 34:15-29.

Harmankaya, M., M. Önder, M. Hamurcu, E. Ceyhan, and S. Gezgin. 2008. Response of common bean (Phaseolus vulgaris $\mathrm{L}$.) cultivars to foliar and soil applied boron in boron deficient calcareous soils. Afr. J. Biotechnol. 7:3275-3282.

Hoagland, D.R. and D.I. Arnon. 1950. The water culture method for growing plants without soils. California Agricultural Experimental Station, Berkeley.

Inbaraj, M.P. and K. Muthuchelian. 2011. Effect of boron and high irradiance stresses on chlorophyll, protein and starch content in leaves of cowpea (Vigna unguiculata L. Walp. P152). J. Biosci. Res. 2:55-61.

Karan, D., S.B. Singh, and Ramkewal. 2014. Effect of zinc and boron application on yield of lentil and nutrient balance in the soil under indo-gangetic plain zones. J. AgriSearch. 1:206-209.

Karnovsky, M.J. 1965. A formaldehyde glutaraldehyde fixative of high osmolarity for use in electron microscopy. J. Cell Biol. 27:137-138.

Kirkby, E.A. and V. Römheld. 2007. Micronutrientes na fisiologia de plantas: Funções, absorção e mobilidade. Inf. Agron. 118:1-24.

Lavres Júnior, J., C.P. Cabral, M.L. Rossi, T.A.R. Nogueira, N.L. Nogueira, and E. Malavolta. 2012. Deficiency symptoms and uptake of micronutrients by castor bean grown in nutrient solution. Rev. Bras. Ciên. Solo. 36:233-242.

Marschner, H. 1995. Mineral nutrition of higher plants. Academic Press, London.

Oliveira, I.P. and J.P. Dantas. 1984. Sintomas de deficiências nutricionais e recomendações de adubação para o caupi. EMBRAPA-CNPAF, Goiânia. 23 p. (Documentos 8).

Padbhushan, R. and D. Kumar. 2015. Yield and nutrient uptake of green gram (Vigna radiata L.) as influenced by boron application in boron-deficient calcareous soils of Punjab. Commun. Soil Sci. Plant Anal. 46:908-923.

Pan, Y., Z. Wang, L. Yang, Z. Wang, L. Shi, R. Naran, P. Azadi, and F. Xu. 2012. Differences in cell wall components and allocation of boron to cell walls confer variations in sensitivities of Brassica napus cultivars to boron deficiency. Plant Soil 354:383-394.
Prado, R.M. 2008. Nutrição de Plantas. 1st ed. Editora UNESP, São Paulo.

Rahman, I.U., A. Afzal, Z. Iqbal, F. Ijaz, S. Shad, S. Manan, and M. Afzal. 2014. Response of common bean (Phaseolus vulgaris L.) to basal applied and foliar feeding of different nutrients application. American-Eurasian J. Agr. \& Environ. Sci. 14:851-854.

Reynolds, E.S. 1963. The use of lead citrate at high $\mathrm{pH}$ as an electron-opaque stain in electron microscopy. J. Cell Biol. 17:208-212.

Rodríguez-Lucena, P., N. Tomasi, R. Pinton, L. Hernández-Apaolaza, J.J. Lucena, and S. Cesco. 2009. Evaluation of ${ }^{59} \mathrm{Fe}$-lignosulfonate complexes as Fe sources for plants. Plant Soil 325:53-63.

Salameh, A.K., L.J. Mauer, and L.S. Taylor. 2005. Deliquescence lowering in food ingredient mixtures. J. Food Sci. 71:10-16.

Siddiqi, M.Y. and A.D.M. Glass. 1981. Utilization index: A modified approach to the estimation and comparison of nutrient efficiency in plants. J. Plant Nutr. 4:289-302.

Singh, A.K., Shashank, and A. Srivastav. 2014 Effect of boron application on seed yield and protein content of mungbean (Vigna radiata $\mathrm{L}$.). Curr. Adv. Agr. Sci. 6:67-68.

Stangoulis, J.C.R., P.H. Brown, N. Bellaloui, R.J. Reid, and R.D. Graham. 2001. The efficiency of boron utilisation in canola. Austral. J. Plant Physiol. 28:1109-1114.

Subbarayappa, C.T., S.C. Santhosh, N. Srinivasa, and V. Ramakrishnaparama. 2009. Effect of integrated nutrient management on nutrient uptake and yield of cowpea in southern dry zone soils of Karnataka. Mysore J. Agr. Sci. 43:700-704.

Swiader, J.M., Y.E. Chyan, and F.G. Freiji. 1994. Genotypic differences in nitrate uptake and utilization efficiency in pumpkin hybrids. J. Plant Nutr. 17:1687-1699.

Theerakulpisut, P. and W. Gunnula. 2012. Exogenous sorbitol and trehalose mitigated salt stress damage in salt-sensitive but not salttolerant rice seedlings. Asian J. Crop Sci. $4: 165-170$.

van Raij, B., H. Cantarella, J.A. Quaggio, and A.M.C. Furlani. 1996. Recomendações de adubação e calagem para e Estado de São Paulo. 2nd ed. Campinas: Instituto Agronômico \& Fundação IAC.

Will, S., T. Eichert, V. Fernández, J. Möhring, T. Müller, and V. Römheld. 2011. Absorption and mobility of foliar-applied boron in soybean as affected by plant boron status and application as a polyol complex. Plant Soil 344:283-293.

Will, S., T. Eichert, V. Fernández, T. Müller, and V. Römheld. 2012. Boron foliar fertilization of soybean and lychee: Effects of side of application and formulation adjuvants. J. Plant Nutr. Soil Sci. 175:180-188.

Zhang, Y., Z. Ding, F. Ma, R.D. Chauhan, D.K. Allen, T.P. Brutnell, W. Wang, M. Peng, and P. Li. 2015. Transcriptional response to petiole heat girdling in cassava. Sci. Rep. 5:1-9. 